\section{Repair Strength in Simulated Restorations of Methacrylate- or Silorane-Based Composite Resins}

\author{
Rafael Leonardo Xediek Consani ${ }^{1}$, Tatiane Marinho ${ }^{1}$, Atais Bacchi ${ }^{2}$, Ricardo \\ Armini Caldas ${ }^{1}$, Victor Pinheiro Feitosa ${ }^{3}$, Carmem Silvia Pfeifer ${ }^{4}$
}

\author{
'Department of Prosthodontics \\ and Periodontology, Piracicaba \\ Dental School, Universidade de \\ Campinas, Piracicaba, SP, Brazil \\ ${ }^{2}$ UPF - Universidade de Passo \\ Fundo, Passo Fundo, RS, Brazil \\ ${ }^{3}$ Post-Graduation Program in \\ Dentistry, Health Sciences Center, \\ UFCE - Universidade Federal do \\ Ceará, Fortaleza, CE, Brazil \\ ${ }^{4}$ Biomaterials and Biomechanics, \\ OHSU, Portland, OR, USA
}

Correspondence: Rafael Leonardo Xediek Consani, Avenida Limeira 901, 13414-903 Piracicaba, SP, Brasil. Tel: +55-19-2106-5296. e-mail: rconsani@fop.unicamp.br

\begin{abstract}
The study verified the bond strength in simulated dental restorations of siloraneor methacrylate-based composites repaired with methacrylate-based composite. Methacrylate- (P60) or silorane-based (P90) composites were used associated with adhesive (Adper Single Bond 2). Twenty-four hemi-hourglass-shaped samples were repaired with each composite $(n=12)$. Samples were divided according to groups: $\mathrm{G} 1=\mathrm{P} 60+$ Adper Single Bond 2+P60; G2= P60 + Adper Single Bond 2 + P60 + thermocycling; G3 = P90 + Adper Single Bond $2+$ P60; and G4= P90 + Adper Single Bond $2+P 60+$ thermocycling. $\mathrm{G} 1$ and $\mathrm{G} 3$ were submitted to tensile test $24 \mathrm{~h}$ after repair procedure, and $\mathrm{G} 2$ and $\mathrm{G} 4$ after submitted to 5,000 thermocycles at 5 and $55^{\circ} \mathrm{C}$ for $30 \mathrm{~s}$ in each bath. Tensile bond strength test was accomplished in an universal testing machine at crosshead speed of 0.5 $\mathrm{mm} / \mathrm{min}$. Data (MPa) were analyzed by two-way ANOVA and Tukey's test (5\%). Sample failure pattern (adhesive, cohesive in resin or mixed) was evaluated by stereomicroscope at $30 \times$ and images were obtained in SEM. Bond strength values of methacrylate-based composite samples repaired with methacrylate-based composite (G1 and G2) were greater than for silorane-based samples (G3 and G4). Thermocycling decreased the bond strength values for both composites. All groups showed predominance of adhesive failures and no cohesive failure in composite resin was observed. In conclusion, higher bond strength values were observed in methacrylate-based resin samples and greater percentage of adhesive failures in silorane-based resin samples, both composites repaired with methacrylate-based resin.
\end{abstract}

\section{Inroduction}

Despite the development of new restorative materials and recent clinic techniques, the dental restorations made with composite resins have shown limited performance in long time, which can lead to a restorative repetitive cycle, with possible weakening of tooth due to mineralized tissue loss. In this context, the repair in composite restorations appears to be a less invasive alternative method when correctly indicated (1).

Chemical solutions may affect the physical and mechanical properties of these materials by the effects of the solvent uptake and elution of components. However, in long-term the elution of degradation products in the oral cavity (2) compromises the longevity of the dental restoration and decreases the capacity of restoration repair (3). In addition, different surface treatments produce different bond strengths for the repair of recent restorations of silorane- and methacrylate-based composites (4). These factors are the rationale to verify the behaviour of repair in the composite restorations.

Surface roughness, bond type, repair materials and aging are variables that affect the adhesive strength between aged and recently added resin. In repaired restorations, the bond between aged and repair resins and also between the layers of new resin is dificulted by the inhibiting layer of polymerization caused by oxygen. Nevertheless, the amount of unsaturated double bonds decreases with aging, reducing the bond strength between increments (aged and repair). Thus, some techniques are recommended to improve the bond strength of aged composite resins. Micro-interlocking (roughness) and other procedures are based on attempts to improve the resin adhesion by links between the new polymeric matrix and the filler particles of the aged resin (5), and it depends on whether the material is used as filling or for the repair of material (6). Surface roughness can be mechanically obtained by means of diamond points or blasting with aluminum oxide particles and chemically etched with hydrofluoric or phosphoric acid. Therefore, both procedures are employed to remove the aged layer of resin and create roughness for increasing the bond strength.

Silanes and unfilled resins are traditionally used as bond agents for restoration repairs. Silanes promote chemical bond between resin and filler particles, and may also increase the ability to wet the adhesive onto the surface roughness. Moreover, the adhesive promotes chemical bond between the organic matrices of the new composite and the old resin to be repaired (5). Different from the traditional system of polymerization, silorane-based composites use the cationic 
polymerization mechanism with lower shrinkage values and polymerization stress at tooth-restoration interface. Consequently, it has been alleged that some drawbacks are avoided or minimized, such as cusp deflection, crack propagation in enamel and failures at the bond interface, resulting in microorganism contamination and consequent pulp damage (7).

Bond strength of aged methacrylate- or silorane-based composites using the same repair resin related to surface treatments was recently evaluated (8). However, siloranes have been claimed as materials to be withdrawn from the dental market. The aim of this study was to verify the bond strength of repairs in simulated restorations of methacrylate- or silorane-based composite resins using methacrylate-based composite resin. The tested hypothesis was that bond strength values of repairs made with methacrylate-based resin in methacrylate- or silorane-based simulated restorations would be similar.

\section{Material and Methods}

\section{Hemi-hourglass Shaped Samples Preparation}

Twenty-four hourglass-shaped matrices $(13 \mathrm{~mm}$ long, $2 \mathrm{~mm}$ thick, $6 \mathrm{~mm}$ wide at the ends and $3 \mathrm{~mm}$ wide in t the central region) of Filtek P60 (methacrylate-based; 3M ESPE, St. Paul, MN, USA) and Filtek P90 (silorane-based; 3M ESPE) resin composites were obtained using silicone molds (Zetalabor; Zhermack, Rovigo, Italy) (8) (Table 1). Four composite increments were used to fill the mold, each increment activated by a light-curing unit (Ultra-Lume LED; Ultradent, South Jordan, UT, USA) at $800 \mathrm{~mW} / \mathrm{cm}^{2}$ for 20 s. A glass plate was used to press the last increment during photoactivation. Next, the matrices were stored in an oven at $37^{\circ} \mathrm{C}$ for 6 months in distilled water.

After storage, the hourglass-shaped matrices were sectioned in the central portion obtaining 48 hemi-hourglass matrices for each composite resin. The bond surfaces of the composite matrices were submitted to mechanical abrasion with 600-grit $\mathrm{Al}_{2} \mathrm{O}_{3}$ paper (Norton, Guarulhos, SP, Brazil) for $10 \mathrm{~s}$, ultrasonically cleaned (Vitasonic; Vita, Germany) in distilled water for $10 \mathrm{~min}$ and air jet dried. The bond surface was etched with a thin layer of silane (Angelus, Londrina, $P R$, Brazil) with 1 min drying. A thin layer of adhesive
(Adper Single Bond 2; 3M ESPE) was applied on the bond surface for 10 s and air thinned according to manufacturer's instructions. The adhesive activation was made with a LED light-curing unit (Ultradent) at $800 \mathrm{~mW} / \mathrm{cm}^{2}$ for $20 \mathrm{~s}$. After these procedures, the composite hemi-hourglass-shaped matrices were divided according to following groups $(n=12)$ : G1: P60 + Adper Single Bond 2 + P60; G2: P60 + Adper Single Bond $2+$ P60 + thermocycling; G3: P90 + Adper Single Bond 2 + P60; and G4: P90 + Adper Single Bond 2 + P60 + thermocycling.

\section{Repair Procedure of the Hemi-Hourglass-Shaped Samples}

Each hemi-hourglass-shaped composite matrix was placed into the silicone mold and the remaining part was filled with four increments of restorative composite, according to the experimental groups established in the study. The first three increments were photoactivated for $20 \mathrm{~s}$ each one and the last increment pressed by a glass plate during photoactivation for $20 \mathrm{~s}$. After mold removal, the repaired sample was additionally activated for $40 \mathrm{~s}$. All activation procedures were carried out with a LED unit (Ultradent) at $800 \mathrm{~mW} / \mathrm{cm}^{2}$.

$\mathrm{G} 1$ and $\mathrm{G} 3$ repaired samples were tensioned after storage at relative humidity for $24 \mathrm{~h}$, while the $\mathrm{G} 2$ and $\mathrm{G} 4$ repaired samples were tensioned after 5,000 thermal cycles (MSCT thermocycler; Geraldeli ME, São Carlos, SP, Brazil) at 5 and $55^{\circ} \mathrm{C}$ in $30 \mathrm{~s}$ baths for each temperature.

\section{Bond Strength Test}

Repaired samples were fixed with cyanoacrylate glue (Super Bonder Gel; Loctite, Diadema, SP, Brazil) associated with instant cure accelerator (Tak Pak Accelerator; Loctite) in a Bencor-MultiT modified device adapted to an universal testing machine (4411 model; Instron, Canton, MA, USA) and tensioned at a crosshead speed of $0.5 \mathrm{~mm} / \mathrm{min}$ until failure.

The transverse dimensions of the failures were measured with a digital caliper (Mitutoyo; Tokyo, Japan) and the values utilized for bond area calculation. Data for bond strength were evaluated for normality by KolmogorovSmirnov and the heterocedasticity of variances by Levene's tests. Data distribution was normal and the variances were

Table 1. Restorative composites and formulation

\begin{tabular}{lccc}
\hline Material & Resin & Organic matrix & Fillers \\
\hline Filtek P90* & Silorane & 3,4-epoxycyclohexylethycyclo polymethylsiloxane, & 76 wt.\% quartz, yttrium fluoride \\
Filtek P60 & Bis 3,4-epoxycyclohexylethylphenylmethysilane & 84 wt.\% zirconia/silica \\
\hline
\end{tabular}

Lot number $={ }^{*} \mathrm{~N} 136711 ;{ }^{\dagger} \mathrm{N} 138420$. Bis-GMA: Bisphenol A glycidyl dimethacrylate; UDMA: urethane dimethacrylate; Bis-EMA: ethoxylated Bisphenol A dimethacrylate. 
homogenous. Following, the data ( $\mathrm{MPa}$ ) were submitted to two-way ANOVA and the mean values compared by the Tukey's test $(\alpha=0.05)$. The analyzed factors were composite resin and treatments ( $24 \mathrm{~h}$ and thermocycled).

\section{Failure Pattern}

Failure pattern of the failured surface was evaluated with a stereomicroscope (EMZ-TR; Meiji Techno, Tokyo, Japan) at 30x magnification by a single examiner and the results analyzed by all authors. Failure patterns were considered as adhesive, cohesive in resin or mixed. Representative failure of each group was processed for SEM analysis as follows: both parts of the failured sample were paired, air dried, mounted on aluminum stub, gold coated and SEM (JSM-

Table 2. Means and standard deviation of the bond strength values (MPa) for methacrylate- or silorane-based samples

\begin{tabular}{lccc}
\hline Based-sample & $24 \mathrm{~h}$ & Thermocycled & Mean \\
\hline $\begin{array}{l}\text { Methacrylate } \\
\text { (G1 and G2) }\end{array}$ & $6.95 \pm 1.8 \mathrm{aA}$ & $6.04 \pm 1.8 \mathrm{bA}$ & $6.50 \pm 0.6 \mathrm{~A}$ \\
$\begin{array}{l}\text { Silorane } \\
\text { (G3 and G4) }\end{array}$ & $5.80 \pm 1.7 \mathrm{aB}$ & $4.27 \pm 1.2 \mathrm{bB}$ & $5.03 \pm 1.1 \mathrm{~B}$ \\
Mean & $6.37 \pm 0.8 \mathrm{a}$ & $5.16 \pm 1.2 \mathrm{~b}$ & - \\
\hline
\end{tabular}

Different small letters in rows and capital letters column differ by Tukey's test $(\alpha<0.05)$.

5600LV, JEOL; Tokyo, Japan) examined at 15 kV.

\section{Results}

Table 2 shows that the methacrylate-based composite samples repaired with methacrylate-based composite presented higher and statistically significant bond strength values ( $p=0.002)$ compared to silorane-based samples. The thermocycling procedure decreased significantly the bond strength values for all repaired samples ( $p=0.007)$.

Table 3 shows prevalence of adhesive failures in all groups (\%). G1 (24 h) and G2 (thermocycled) methacrylate groups showed $41 \%$ and $32 \%$ of mixed failures, respectively, whereas $\mathrm{G} 3(24 \mathrm{~h}$ ) and $\mathrm{G} 4$ (cycled) silorane groups presented $18 \%$ and $0 \%$ of mixed failures, respectively. No cohesive failure in composite resin was observed in the groups with and without thermocycling. SEM evaluations of failures

Table 3. Sample failure pattern (\%) for metacrylate- or siloranebased samples

\begin{tabular}{ccccc}
\hline \multirow{2}{*}{ Failure } & \multicolumn{2}{c}{ Methacrylate } & \multicolumn{2}{c}{ Silorane } \\
\cline { 2 - 5 } & G1 (24 h) & $\begin{array}{c}\text { G2 } \\
\text { (cycled) }\end{array}$ & G3 (24 h) & G4 (cycled) \\
\hline Adhesive & $59 \%$ & $68 \%$ & $82 \%$ & $100 \%$ \\
Mixed & $41 \%$ & $32 \%$ & $18 \%$ & $0 \%$ \\
\hline
\end{tabular}
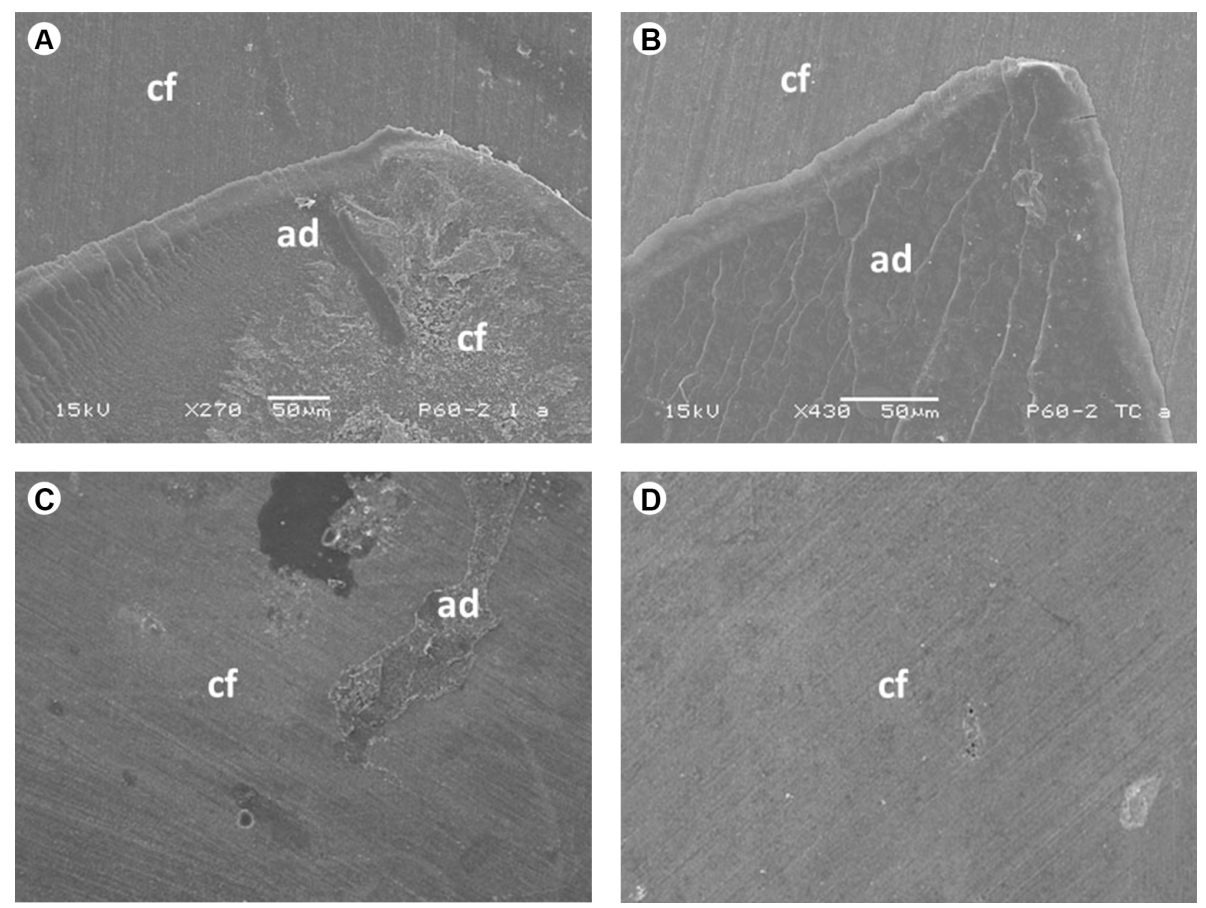

Figure 1. Representative SEM images of debonded samples. A: G1 (P60 + P60 24 h): Mixed failure involving old composite (cf) and adhesive layer (ad). B: G2 (P60 + P60 cycled): Mixed failure in old composite (cf) and adhesive substrate (ad). Although G1 and G2 groups presented statistically significant difference for bond strength values, the SEM images shows similar mixed failures involving old material and adhesive layer. C: G3 (P90 + P60 24 h): Large area of adhesive failure beteeen the old composite (cf), the adhesive layer (ad) and a small region of adhesive. D: G4 (P90 + P60 cycled): Complete adhesive failure showing only old composite (cf). 
observed in G1 (24 h), G2 (cycled), G3 (24 h) and G4 (cycled) groups are shown in Figure 1.

\section{Discussion}

This study evaluated the bond strength of methacrylateor silorane-based samples repaired with methacrylate-based composite before and after thermocycling procedures. The tested hypothesis that bond strength values of repairs with methacrylate-based resin in methacrylate- or silorane-based simulated restorations would be similar was not accepted.

Repairs of composite resins are usually performed months or years after the dental restoration because exposition time in the oral environment promotes water sorption, chemical degradation and leaching of components. In addition, free radicals are responsible for the adhesion among different layers of the restorative composite resin (9). It is possible that the chemical adhesion between new and old resins did not establish a reliable bonding in chemical conditions, considering that the quantity of free radicals decreases with the aging of dental restoration (10).

These conditions related to adhesion can affect the repair success, changing the bond strength value due to the microstructural characteristics and composition of the composite resin (3). Since silorane is considered a tetra-functional molecule with greater molecular weight than other components used in most methacrylate-based materials, the component leached levels are less evident, even considering that the degree of conversion of the material is smaller (11). However, epoxy groups polymerized by cationic mechanism may be less available for chemical reaction on the material surface than the polymeric products. This fact would explain the difference in bond strength when compared with composite resins, where the methacrylate-based composite resin showed greater bond strength than silorane-based composite (Table 2).

Mechanical interlocking is the most significant factor to increase the bond strength of resin repairs (12) and incremental shear bond strength was achieved by aluminum oxide sandblasting and silica coating (13). Thus, mechanical surface treatments have been suggested to increase the roughness and free surface energy. This procedure also removes the superficial layer of resin deteriorated by the oral environment (4), and increases the possibility of the material to offer a greater amount of carbon with the available free linkage (14). Moreover, surface treatment with diamond points and hydrofluoric acid etching promotes smaller bond strength when compared to other abrasive treatments (13).

A previous study considered the silane etching as a decisive factor for adhesion of methacrylate-based resin on siloxane surfaces (15). Silanes and free-filler resins are traditionally used as bond agents for repair due to the capacity for linkage with filler particles and to bond with the organic matrix (3).

Thermocycling is more effective for degradation of composite resins that other aging methods (16). The number of cycles is considered the most influential factor to alter the effect of thermocycling. According to ISO, 500 cycles in water between 5 and $55^{\circ} \mathrm{C}$ are considered appropriate for aging dental materials (17). If an analogy is possible, results from previous work showed that 500 cycles were not enough to affect the bond strength between composite resins and dentin (18), whereas the thermocycling effect on the bond strength of composite resins was more effective when performed at 5,000 cycles (16). In the current study, it may be noted that the bond strength decreased when the samples were submitted to thermocycling and the values presented statistically significant difference among groups (Table 2). This result may be explained by the degradation of the adhesive interface due to water sorption, chemical changes and consequent leaching of some components.

Table 3 shows the failure pattern (\%) of the debonded samples. Although showing prevalence of adhesive failures, $\mathrm{G} 1$ (24 h) and G2 (cycled) methacrylate groups presented also mixed failures. In the $\mathrm{G} 1$, the percentage of mixed failures was greater compared to G2. Probably, less deterioration of the adhesive interface of the $\mathrm{G} 1$ samples was responsible for this result compared to thermocycled $\mathrm{G} 2$ group. The $\mathrm{G} 3$ (24 h) and G4 (cycled) silorane groups showed prevalence of adhesive failures, result due to the lesser amount of free carbons to react with the repair resin, considering that this material is a silorane-based composite resin. When silorane groups were compared, G3 samples presented small percentage of mixed failures, while G4 showed only adhesive failures, results consistent with the difference of bond strength values observed in these groups. Previous works showed cohesive failures more frequently than adhesive failures when the silane agent was applied or when silorane composite was used for repair (13); groups with silane and bonding agent had the highest strength values, showing a reasonable number of cohesive failures (19). In the present study, although repaired with methacrylate-based material, the group with silorane-based material showed predominance of adhesive failures. A previous study showed that after aluminum oxide sandblasting, the aged silorane resin repaired with either silorane resin composite with Filtek LS system adhesive or methacrylate resin composite with methacrylate dental adhesive presented primarily adhesive failures in all groups (20).

Conversely, due to different effect of the microstructure on the mechanical behavior of the composite resin (3), there is no standard protocol for repair procedures in all clinical situations, as the knowledge of the material composition is a crucial factor for the success of repair (21). However, 
although thermocycling has decreased the bond strength of methacrylate-based samples, this procedure could be considered a reliable clinical alternative for situations in which the repair can be made with the same material of the restoration, considering the percentage of mixed failures observed for the $\mathrm{G} 1$ and $\mathrm{G} 2$ groups (Table 3). In terms of clinical performance, it was shown that after two years the result for silorane-based composite was similar to the dimethacrylate-based composite, except for marginal discoloration in the silorane-based restorations (22).

Although a statistically significant difference was observed for bond strength values between G3 and G4 groups, both silorane samples showed predominance of adhesive failures. $\mathrm{G} 3$ shows small amount of adhesive layer on a larger region of old substrate, whereas G4 presented totally adhesive failure. In conclusion, higher bond strength values were observed in methacrylate-based resin samples and greater percentage of adhesive failures in silorane-based resin samples, both composites repaired with methacrylatebased resin.

\section{Resumo}

0 objetivo neste estudo foi verificar a resistência de união em restaurações simuladas de compósitos baseados em metacrilato ou silorano reparadas com compósito à base de metacrilato. Compósitos baseados em metacrilato (Filtek P60; 3M ESPE) ou silorano (Filtek P90; 3M ESPE) foram associados com adesivo (Adper Single Bond 2; 3M ESPE). Vinte e quatro amostras em forma de semi-ampulhetas foram reparadas com cada material $(n=12)$, conforme os grupos experimentais: G1- P60 + Adper Single Bond 2 + P60; G2- P60 + Adper Single Bond 2 + P60 + termociclagem; G3- P90 + Adper Single Bond 2 + P60; e G4- P90 + Adper Single Bond 2 + P60 + termociclagem. Os grupos G1 e G3 foram submetidos ao ensaio de tração após 24 horas do procedimento de reparo e os grupos $\mathrm{G} 2$ e $\mathrm{G} 4$ depois de submetidos a 5.000 ciclos térmicos de 5 e $55^{\circ} \mathrm{C}$ por $30 \mathrm{~s} \mathrm{em} \mathrm{cada} \mathrm{banho.} 0$ teste de resistência à tração foi efetuado em máquina universal atuando numa velocidade de $0,5 \mathrm{~mm} / \mathrm{min}$. Os dados (MPa) foram submetidos a ANOVA a dois fatores e teste de Tukey (5\%). 0 padrão de fratura das amostras (adesivo, coesivo em resina ou misto) foi avaliado em estereomicroscópio com aumento de 30x e imagens representativas foram obtidas em MEV. Os valores de resistência à tração das amostras feitas com compósito à base de metacrilato e reparadas com compósito à base de metacrilato ( $\mathrm{G} 1$ e G2) foram maiores do que nas amostras feitas com compósito à base de silorano e reparadas nas mesmas condições ( $\mathrm{G} 3$ e $\mathrm{G} 4$ ). A termociclagem diminuiu os valores de resistência à tração para ambos os compósitos. Todos os grupos mostraram predominância de fraturas adesivas e nenhuma falha coesiva foi observada em compósito. Em conclusão, valores maiores de resistência à tração foram observados em amostras de resina à base de metacrilato e maior porcentagem de fraturas adesivas nas amostras de resina à base de silorano, ambos os compósitos reparados com resina à base de metacrilato.

\section{Acknowledgments}

The authors thank to CNPq/UNICAMP/PIBIC program to the support for the development of this research at Piracicaba Dental School, Universidade de Campinas, SP, Brazil. international survey of the teaching of operative techniques and materials. Eur J Dent Educ 2003;7:41-48.

2. Ferracane JL. Hygroscopic and hydrolytic effects in dental polymer networks. Dent Mater 2006;22:211-222.

3. Rodrigues SA, Ferracane JL, Della Bona A. Influence of surface treatments on the bond strength of repaired resin composite restorative materials. Dent Mater 2009;25:442-451.

4. Kabeko M, Caldas RA, Feitosa VP, Consani RLX, Schneider LF, Bacchi A. Influence of surface treatments to repair recent fillings of silorane- and methacrylate-based composites. J Conserv Dent 2015;18:242-246.

5. Hannig C, Laubach S, Hahn P, Attin T. Shear bond strength of repaired adhesive filling materials using different repair procedures. J Adhes Dent 2006;8:35-40.

6. Baur V, llie N. Repair of dental resin-based composites. Clin Oral Investig 2013:17:601-608.

7. Palin WM, Fleming GJP, Nathwani H, Burke FJT, Randall RC. In vitro cuspal deflection and microleakage of maxillary premolars restored with novel low-shrink dental composites. Dent Mater 2005; 21:324-335.

8. Bacchi A, Consani RLX, Sinhoreti MA, Feitosa VP, Cavalcante LM, Pfeifer CS, et al.. Repair bond strength in aged methacrylate- and siloranebased composites. J Adhes Dent 2013;15:447-452.

9. Rathke A, Tymina $Y$, Haller B. Effect of different surface treatments on the composite-composite repair bond strength. Clin Oral Investig 2009;13:317-323.

10. Ghivari S, Chandak M, Manvar N. Role of oxygen inhibited layer on shear bond strength of composites. J Conserv Dent 2010;13:39-41.

11. Craig R, Powers J. Restorative Dental Materials. 11th ed., Mosby, USA; 2002.

12. Kusgoz A, Ülker M, Yesilyurt C, Yoldas OH, Ozil M, Tanriver M. Siloranebased composite: depth of cure, surface hardness, degree of conversion, and cervical microleakage in Class II cavities. J Esthet Restor Dent 2011;23:324-335.

13. Wiegand A, Stawarczyk B, Buchalla W, Taubock $\Pi$, Ozcan M. Attin T. Repair of silorane composite - using the same substrate or a methacrylate-based composite? Dent Mater 2012;28:e19-e25.

14. Kimyai S, Mohammadi N, Navimipour EJ, Rikhtegaran S. Comparison of the effect of three mechanical surface treatments on the repair bond strength of a laboratory composite. Photomed Laser Surg 2010;28 Suppl 2:S25-S30.

15. Ivanovas $S$, Hickel $R$, llie N. How to repair fillings made by silorane-based composites. Clin Oral Investig 2011;15:915-922.

16. Ozcan M, Barbosa SH, Melo RM, Galhano GA, Bottino MA. Effect of surface conditioning methods on the microtensile bond strength of resin composite to composite after aging conditions. Dent Mater 2007;23:1276-1282.

17. Xie $C_{1}$ Han $Y$, Zhao $X Y$, Wang $Z Y$, He HM. Microtensile bond strength of one- and two-step self-etching adhesives on sclerotic dentin: the effects of thermocycling. Oper Dent 2010;35:547-555.

18. Nikaido $T$, Kunzelmann $\mathrm{KH}$, Chen $\mathrm{H}$, Ogata $\mathrm{M}$, Harada $\mathrm{N}$, Yamaguchi $\mathrm{S}$, et al.. Evaluation of thermal cycling and mechanical loading on bond strength of a self-etching primer system to dentin. Dent Mater 2002;18:269-275.

19. Hamano N, Chiang YC, Nyamaa I, Yamaguchi $H$, Ino $S$, Hickel $R$, et al.. Repair of silorane-based dental composites: influence of surface treatments. Dent Mater 2012;28:894-902.

20. Palasuk J, Platt JA, Cho SD, Levon JA, Brown DT, Hovijitra ST. Effect of surface treatments on microtensile bond strength of repaired aged silorane resin composite. Oper Dent 2013;38:91-99.

21. Loomans BA, Cardoso MV, Roeters FJ, Opdam NJ, De Munck J, Huysmans $M C$, et al.. Is there one optimal repair technique for all composites? Dent Mater 2011;27:701-709.

22. Popoff DA, Magalhaes CS, Freitas Oliveira W, Soares LA, Almeida Santa Rosa $\Pi$, Moreira AN, et al.. Two-year clinical performance of dimethacrylate-based acomposite restorations repaired with a siloranebased composite. J Adhes Dent 2014;16:575-583.

\section{References}

1. Blum I, Schriever A. The repair of direct composite restorations: An 